See discussions, stats, and author profiles for this publication at: https://www.researchgate.net/publication/248881244

\title{
Closed space and political practice: Frederick Jackson Turner and Halford Mackinder
}

Article in Environment and Planning D Society and Space · January 1984 DOI: 10.1068/d020023

CITATIONS

32

1 author:

Gerry Kearns

Maynooth University

113 PUBLICATIONS 777 CITATIONS

SEE PROFILE

Some of the authors of this publication are also working on these related projects:

Colonial and Postcolonial Ireland View project 


\section{Closed space and political practice: Frederick Jackson Turner and Halford Mackinder}

\section{G Kearns}

Department of Geography, University of Liverpool, PO Box 147, Liverpool L.69 3BX. England

Recoived 7 Docombor 1982; in rovised form 22. August 1983

Abstract. Turner's fronticr thesis and Mackinder's heartland thesis are examples of closed-space thinking. Closed-space theories were current at the beginning of this century when public debate was penetrated both by biology and by geography. This conjuncture allowed spatial concepts to form the basis for the theoretical arguments advanced for political positions. The internal structure of closed-space theorics allowed them to promote political conclusions, because the three central terms of those theories (environment, history, recent fundamental changes) were 'essentially contestable' and capable of interpretations which supported particular political arguments. The specific political arguments promoted by Turner and Mackinder dictated the interpretations they chose and thus the internal structure of their theories. The political significance of their work was tied to the existence of two inherently unstable political alliances riven with economic contradictions. This emphasis on the internal structure of these theories enables one to appreciate how they could convince, and both the content and the logic of these approaches are amenable to contextual interpretation.

In 1944, James Malin commented on the similar conception of space at the core of the works of the US historian, Frederick Jackson Turner (1861-1932), and the UK geographer, Halford Mackinder (1861-1947). Malin (1944) suggested that Turner's frontier thesis and Mackinder's geopolitcal writings were examples of 'closed-space' thinking. Turner warned of the effects of the passing of empty lands for settlement in the USA, and Mackinder drew attention to the consequences of a similar situation on a world scale. Malin does not offer a satisfactory explanation of this coincidence and merely remarks that closed-space ideas were 'in the air' at the time. Here, I develop further Malin's suggestive thesis by drawing on more recent scholarship to provide a more detailed account of the context of these 'closed-space' theories.

I also attempt in this paper to make a contribution to the development of a contextual approach in the historiography of geography and to the criticism of positivist alternatives (contrast Stoddart, 1981 b, and Johnston, 1979). Geographers are obviously influenced by a wide range of factors external to the narrower concerns identified by their professional labels. However, if the contextual approach is to amount to anything more than a hunt for so-called influences, then it must carefully specify exactly how these influences work. This has been attempted in several ways within social theory, but, broadly speaking, the aim is to identify a discursive object and to describe the effects of its nondiscursive relations. Thus one might try to identify some of that discourse's external conditions of existence or application (for example, see Teymur, 1982, pages 160-179). These efforts will be unsatisfactory unless they incorporate a more sophisticated appreciation of the organisation of discourse than is evidenced in many contextual analyses of geographic work.

Discourse analysis is a fairly straightforward task if one believes that all theories or academic statements are essentially coherent, that all theories and statements derive from initial presuppositions or assumptions which inevitably surface in and irredeemably mark the conclusions offered within those theories or statements. Contextual analysis can then proceed by demonstrating the contemporary grounding of certain geographers' basic assumptions and thereby claiming that any resulting work must bear the impress of this template. This has the effect of justifying a contextual analysis of a body of geographic work which refers almost exclusively to the broader 
intentions of the geographer and hardly at all to the actual details of their work beyond a description of its central themes (for example, see Blouet, 1975).

Hindess has attacked this "rationalist conception of the production of discourse" (Hindess, 1977, page 21; also see chapter 7 passim). Discourse, he suggests, is frequently fragmented, fractured, and uneven, and all of its components are not necessarily mutually compatible or indispensable. This raises the question of how, if not on the basis of a completely coherent timeless logic, discourses can be made to work, how they can convince. An answer can only be developed by paying much greater attention to the internal structure of theories, to the way their component concepts are placed and related together, to their 'hierarchy of concepts'. Hindess proposes that "there is a hierarchy of concepts to the extent that the formation of certain concepts of a discourse depends on, or 'presupposes', certain other concepts" (1977, page 225). In this paper, I suggest that it is the strategy whereby concepts are deployed that conveys conviction and that, furthermore, these strategies are intimately wedded to particular contexts in which, for example, certain uses of particular analogies are allowed to count as proof at one time whereas they would not constitute a convincing argument at another. In the rest of this paper, I illustrate these claims in attempting to offer a contextual account of the closed-space theories of Turner and Mackinder. It is suggested that the extradiscursive links of their work were developed through disciplinary advocacy and political debate. Both promoted their respective disciplines and claimed that their work had contemporary relevance. The intellectual strategies within their work relied upon a curious overlap between biology and geography. The internal organisation of their work allowed political weight to be attached to three components of their theories: environmentalism, historical processes, and recent fundamental changes. Yet Turner and Mackinder made very different political choices and, consequently, their conceptions of closed space are dissimilar.

Education in context: disciplinary and political advocacy

Both Mackinder and Turner were eager to educate. They both lectured extensively within the university system, but also outside it. Turner was "an enthusiastic advocate" (Billington, 1973, page 94) of extension lectures, giving many lectures between 1891 and 1896. Mackinder gave extension lectures between 1885 and 1903 (Parker, 1982, chapter 1), travelling 30000 miles and giving over 600 lectures in the 1880s (Stoddart, 1981a, page 291), including a staggering 102 in the academic year 1887-1888 alone (Gilbert, 1951, page 28).

Their attempts to promote the contribution of their disciplines to education must be understood in terms of two sets of relations; those between different disciplines and those between academic work and public debate. Their professional commitment was partly channelled into "the university institutionalisation of science" (Capel, 1981, page 65) with all its attendant struggles between areas of knowledge now aspiring to disciplinary status and assiduously establishing their own intellectual pedigrees. Success in this academic imperialism was cultivated in two ways; through acquiring the trappings of intellectual respectability and through proclaiming the relevance of one's particular intellectual concerns.

How was intellectual respectability gained in the context of late-nineteenth-century science? If science is primarily an activity which, as Habermas argues, aims at "the redemption of truth claims" in "argumentative discourse" (MacCarthy, 1978, page 293 and 294), then it must be conceded that in this period most science was evolutionary science. The translation of a problem into biological terms allowed its solution by analogy. All aspects of life were underwritten by the metaphysics of evolution. In the late-nineteenth century, intellectual credibility was indicated by one's proximity to biology, evolutionary biology. 
Russett remarks that "Darwinism reigned over Victorian culture as supremely as Newtonian mechanics had over the previous century" (Russett, 1976, page 19). Stoddart (1975, page 26) concludes that "at that time, the 'stendy application' of what were seen as the 'principles of Darwinism' was thought a science". This was explicitly acknowledged both by Turner and by Mackinder. $\Lambda$ t the outset of his carcer (1883), Turner said that: "Science has of late years revolutionised Zoology, Biology, etc. It must now take up recorded history and do the same by it. This I would like to do my little to aid" (Billington, 1973, page 31). Mackinder also spoke of taking up "modern history with the idea of secing how the theory of evolution would appear in human development" (Blouet, 1975, page 7).

Relevance is always a nebulous term, but it implies a claimed link between academic work and issues of general concern. Both Turner and Mackinder made such claims. In 1896, Turner suggested that education was "a matter of life and death" (Mood, 1949, page 256). More specifically, he belicved that: "the mission of the universitics is most important. The times call for educated leaders. General experience and rulc-of-thumb information are inadequate for the solution of the problems of a democracy which no longer owns the safety net fund of an unlimited quantity of untouched resources" (Turner, 1920b, page 284). Mackinder, likewise, claimed that the geographical imagination he was promoting was highly relevant. In fact, it was "essential to an imperial people. I venture to suggest that when the vote of Englishmen may decide the fate of millions in other parts of the world no less than the progress of our own country, that our aim is here very practical" (Mackinder, 1908, page 8).

The relevance of academic work operated in two directions. First, because these particular academic concerns were 'relevant', their position within the educational institutions was reinforced. Second, there is the extent to which academic work could provide support for particular positions in public debates. Turner and Mackinder had intimate and important connections with public debate. Turner expended a good deal of energy broadcasting the frontier thesis and was its main populariser (Benson, 1969, page 16). He wrote scholarly polemical articles in historical journals and less scholarly but very much more polemical ones for a wide range of the popular press. Furthermore, he found an audience, and editors were anxious to publish whatever he could dash-off about the implications of the dryingup of the supply of free lands for the issues of the day (Billington, 1973, page 200). This is no less true of Mackinder. Mackinder was a member of the Webbs' alternative 'Cabinet of National Efficiency'-the Coefficients (Mackenzie and Mackenzie, 1979, page 290); he resigned as Director of the London School of Economics and Political Science in 1908 to become Milner's foreign-affairs adviser when the latter strove to succeed Chamberlain as leader of the Liberal Unionists (Mackenzie and Mackenzie, 1979, page 356); and he eventually lost his seat in Parliament because the Glasgow working class would not tolerate his prominence in the British efforts to shore up the Tsarist regime in Russia (Blouet, 1975, page 38; also compare Semmel, 1960, pages 166-176 and Parker, 1982, chapter 2).

The study of the educational context of these closed-space theories suggests two further questions: why was this overlap of biology and geography relevant to public debate at this time, and what reciprocal effect did engagement in such debate have upon the work produced by Turner and Mackinder?

Biology and geography: closed space and public debate

Closed-space theories represent a union of biology and geography. How can one explain why that union occurred when it did?

Evolutionary biology was central to late-nineteenth-century public debate. Evolutionary ideas, of various provenances, were built into political positions. 
Freeden believes that: "The revival of the concept of evolution was the prime contribution of biology to nineteenth-century civilisation. Undoubtedly, any sociopolitical theory failing to come to terms with evolutionary thought would have lost its intellectual credibility and its vitality as a solution to the great questions of the time" (Freeden, 1978, page 76). The evolutionary principle was incorporated in several very different and conflicting political positions. This was possible because several of its terms were, in Collini's usual phrase, "essentially contestable" (Collini, 1979, page 15). Yet, although interpretations might vary, more ambitious moves might bring down the dogmatic wrath of the narrow Social Darwinists (Collini, 1979, pages 157-158).

The most important set of reasons why biology was central to public debate concerns the intersection of science and economics in that debate. Public debate in the age of steam, steel, and speed was pretentiously scientific. The contrast with earlier more deferential forms and later less confident forms of debate is clear. Biology took over from philology and geology as the evolutionary science par excellence because it posed most starkly the metaphysical issues involved (Burrow, 1966, page 110). Given the importance of science in public debate, the prominence of biology in the scientific revolution from teleology and description to evolution and causal explanation ensured that it would attain similar prominence in that debate too.

Public debate was also resolutely economic. Economic theory was thought to be directly relevant to a very wide range of issues and it was used in a fairly unsophisticated way. Natural selection effectively involved the biologising of economic laws. Evolutionary biology did not transform economics, but it did give it a significant scientific echo. As Hofstadter suggests: "A broad parallel can be drawn between the patterns of natural selection and classical economics which suggests that Darwinism involved an addition to the vocabulary rather than the substance of economic theory" (Hofstadter, 1944, page 112).

Biology, then, was central to public debate, because that debate was penetrated by science and economics. Biology transformed science, reinforced economics, and brought the two closer together. These developments were afoot in both Britain and the USA, and their consequences are common to both Turner and Mackinder. However, the topicality of a spatial imagination in both countries at this time is perhaps more of a coincidence.

In the late-nineteenth century, says Hofstadter, "the basic dimension of the American imagination is space" (Hofstadter, 1970, page 5). The motor invoked in popular accounts of US development was the passion for space and movement. Indeed: "It was Turner's merit, as well as the source of his defects, to be the first historian to try fully to incorporate this awareness of space, this delight of movement, this yearning for rebirth under natural conditions into our historical thought" (Hofstadter, 1970, page 6). The entry of people into empty space was the repopulation of Eden, and the apple of history was reluctant refreshment for a people believing in their original perfection, for "how can a people progress if they have started near to perfection?" (Hofstadter, 1970, page 7). US historians in fact orchestrated an "escape from history" (Noble, 1965, page 54). They gave people tales of their romantic past: the purity of their Anglo-Saxon heritage and the patriotism of their great heroes. Nothing had changed; perfection had merely incorporated more and more space into its garden of innocence. Turner told the people this story as history and the people were avid readers.

The British preoccupation was with much broader spaces; their gaze was worldwide. Morris speaks of the Diamond Jubilee of Queen Victoria in 1887 as the 'Climax of an Empire': "The Empire had become an official enthusiasm ... . The public surveyed Greater Britain with a proprietorial concern, as though they were inspecting a hitherto neglected piece of family property" (Morris, 1979, page 38). The British 
Empire-comprising a quarter of the world's population and area-was a monumental prize and a responsibility from which the British did not shrink. Imperialism was as much a crusade as an adventure. Mackinder's attempts to popularise a geographical imagination were, therefore, as popular as they were practical. The "instincts" of the British people for "space, power and sacramental dazale" were keen and powerful (Morris, 1979, page 23).

For different reasons, then, geographical perspectives occupied prominent positions in British and US culture, and the problem for Turner and Mackinder was to present their academic and political concerns in the accepted currency of public debate; in the language of evolutionary biology.

Now, to capture this language for a geographical perspective was fairly simple. First, space must be seen as an important requirement of the social organism, and, second, space must be at a premium. This ensured that there would be a struggle for space analogous to the competition of species and the survival of the fittest. The casiest way to do this was to argue that the available space was already filled up, which frustrated the natural tendency of societics to grow or expand spatially. This is exactly what Turner and Mackinder did.

Turner suggested that "the free lands are gone" (Turner, 1920a, page 268); people would have to come to terms with a closed-space existence. Mackinder's rallying cry was similar: the age of exploration had ended (Mackinder, 1904, page 422); there were no more 'uncivilised' countries left to occupy, the world political system was now a closed political system and "men have suddenly realised that the round world has become a closed and locked system" (Mackinder, 1934, page 522).

Certainly, Turner had a point. By 1890, settlement had indeed reached its West Coast outposts. But this was not the end of the supply of free lands, and more land was settled under the Homestead Act (of 1862) after 1890 than had been settled before (Hofstadter, 1955, pages 52-53) and settlement expansion was given a further fillip by subsequent irrigation schemes financed by the government. Similarly, Mackinder was correct in commenting that most of the noncapitalist world had been nominally carved-up by 1900 , but that was not to mark the end of white emigration or the zenith of colonial economic penetration.

Of course, both Mackinder and Turner could claim that they were eventually going to be proved right, but it was the need to capture the language of biology for their geographical perspectives which impelled them to adopt closed-space theories rather than the overwhelming contemporary evidence that this situation had already been reached. Furthermore, their advocacy of the contemporary relevance of their closedspace theories owed more to current political realities than to widespread concern with long-term planning. So, how did they make their theories bear this political weight? How did they negotiate relevant policy concerns through the 'essentially contestable' terms of closed-space ideas?

There are three components of these closed-space theories which were able to bear the contemporary political thrust that Turner and Mackinder wished to convey with their work: their conception of the role of the environment in history; their understanding of the motor behind progressive sequential change in history; and their isolation of fundamental breaks in this historical process. Their political analyses, therefore, were invested with cosmic significance by being tied-in to a restatement of the basic metaphysics of all matter. The next two parts of the paper are summarised in table 1, and the point at stake is that the works of Turner and Mackinder were organised in quite specific ways because of the political lessons they wished to draw. An appreciation of context, then, is essential, not only for understanding the intentions of these two academics, but also for explaining why they produced the spatial analyses they did. In particular, their work was oriented towards two unstable 
political alliances, and an account of those instabilities contributes to an understanding of how their work was received.

Table 1. The internal organisation of the closed-space theories of Turner and Mackinder.

\begin{tabular}{|c|c|c|c|}
\hline $\begin{array}{l}\text { Essentially contestable } \\
\text { terms }\end{array}$ & Biological support & Use by Turner & Use by Mackinder \\
\hline Environmentalism & $\begin{array}{l}\text { environment as control } \\
\text { in the struggle of the } \\
\text { species-natural } \\
\text { selection by ecological } \\
\text { success }\end{array}$ & agrarian myth & $\begin{array}{l}\text { division of human race } \\
\text { into distinct generations; } \\
\text { stage for the struggle of } \\
\text { these generations }\end{array}$ \\
\hline $\begin{array}{l}\text { History as progressive } \\
\text { change }\end{array}$ & $\begin{array}{l}\text { a common teleological } \\
\text { misreading of Darwin }\end{array}$ & frontier process & $\begin{array}{l}\text { increasing mass of } \\
\text { communities; community } \\
\text { conflict end of the age of }\end{array}$ \\
\hline $\begin{array}{l}\text { Discontinuities in the } \\
\text { historical process }\end{array}$ & $\begin{array}{l}\text { the emergence of new } \\
\text { species }\end{array}$ & $\begin{array}{l}\text { closing of the } \\
\text { frontier }\end{array}$ & exploration \\
\hline
\end{tabular}

Turner and closed space: the wilderness, the frontier experience, and the free lands Turner stressed the importance of the environment in history, believing that: "In the settlement of America we have to observe how European life entered the continent and how America modified and developed that life and reacted on Europe. Our early history is the study of European germs developing in an American environment" (Turner, 1920c, page 3). The settlers confronted the environment at the frontier. Initially it was too strong for them, but in taming the wilderness they absorbed some of its influences, rendering the nascent civilisation recognisably unEuropean: "here is a new product that is American" (1920c, page 4). As this new civilisation penetrated deeper into the wilderness, the European influence waned: "moving westward, the frontier becomes more and more American" (1920c, page 4). This Americanisation overcame the effects of the varied origins of the immigrants: "in the crucible of the frontier the immigrants were Americanised, liberated and fused into a mixed race" (1920c, page 23). Frontier conditions fostered an individualism, which produced a democratic tradition independently of imported French or English doctrines: "the frontier individualism has from the beginning promoted democracy (1920c, page 30). The frontier experience combined the regenerative effects of the wilderness with the prior beliefs of the settlers to produce a composite result:

"The stubborn American environment is there with its imperious summons to accept its conditions; the inherited ways of doing things are also there; and yet in spite of the environment and in spite of customs, each frontier did indeed furnish a new field of opportunity, a gate of escape from the bondage of the past, and a freshness and confidence, and scorn of older society, impatience of its restraints and ideas, and indifference to its lessons, have accompanied the frontier" (Turner, 1920c, page 38).

However, Turner does not marshall systematic evidence in favour of his theory, and uses evidence as illustrations of his theory rather than as proof. Turner's paper appealed instead to the assumptions of the agrarian myth: "The agrarian myth represents a kind of homage that Americans have paid to the fancied innocence of their origins" (Hofstadter, 1955, page 24). Turner repeats its praise of the beneficence of nature and the values of the yeoman farmer. Hofstadter (1955, page 25)

demonstrates that: "In origin the agrarian myth was not a popular but a literary idea, a preoccupation of the upper classes, of those who enjoyed a classical education, read pastoral poetry, experimented with breeding stock, and owned plantations or country estates". These ideas were associated with the political claims of the richer farmers, which were initially pressed within the Populist Movement but subsequently outside it. 
The Populist Movement had been "attempting to construct within the framework of American capitalism, some variety of cooperative commonwealth" (Goodwyn, 1978, page 90). Coodwyn sees the defeat of this movement as central to the consolidation of the power of the middle class in America (1978, page xi), and he belicves that this consolidation was primarily secured in cultural terms. The Populist demands were divested of their genuine radicalism and the rhetoric of this party was used as a gloss on the reforms of the Progressive politicians. Turner's work encapsulates this clynamic in bringing together the 'agrarian myth' with a characterisation of history which made room for Progressive reforms.

Turner's history is the story of the frontier process. There is no break in the historical process: "Socicty is an organism, ever-growing. History is the selfconsciousness of this organism ... . There is no break ... . There is unity as well as continuity" (Freunde, 1945, page 82). The people were inextricably linked to their heroic past and this placed upon them certain responsibilities. These responsibilities related to the values forged during the frontier experience.

At each successive frontier, "we have a recurrence of the process of evolution" (Turner, 1920c, page 2). As the density of population increased, the cuitural response of the settlers impelled them along the evolutionary path from hunters to agriculturalists to urban citizens. In this way, the values of frontier democracy are reinternalised at each suceessive frontier as settlement passes through its various stages: "American social development has been continually beginning over again on the frontier. This perennial rebirth, this fluidity of American life, this expansion westwards with its new opportunities, its continuous touch with the simplicity of primitive society, furnish the forces dominating American character" (Turner, 1920c, page 2). The values of independence and individualism were secured by this continual moral regeneration.

Turner isolates the closing of the frontier as a politically significant recent shift in the historical process. He told the people that the frontier had closed in 1900: "The free lands are gone. The material forces that gave vitality to Western democracy are passing away" (Turner, 1920a, page 261). This was symptomatic of a group of changes which, taken together, "constitute a revolution" (1920a, page 244). Turner drev' attention to the "concentration of capital in the control of the fundamental industries"; to the increase in American imperial interests, and to the pressures for state interventionism, which he termed "the importance of socialism as a question dividing the political parties" (1920c, pages 244-246). The view of the revolution clearly reflects the political priorities of the Progressive Party. Turner suggests that the old noninterventionist policies will no longer work and the people must now look to "the realm of ideals and legislation" (1920c, page 261), and he urges: "Let us see to it that the ideals of the pioneer in his log cabin shall enlarge into the spiritual life a democracy where civic power shall dominate and utilise individual achievement for the common good" (1920c, page 268).

Turner's work, therefore, establishes a pedigree for democracy, individualism, and strength in the 'agrarian myth'; forges a link between past values and contemporary processes in his conception of history; and isolates recent changes which make those values essential for the correct government in the closing of the frontier. This historical work was given contemporary power and relevance because it both borrowed the idiom and addressed the issues of public debate. 'Progressive' historians such as Turner "were directed to their major concerns by the political debate of their time; they in turn contributed to it by giving reform politics a historical rationale" (Hofstadter, 1970, page xii). Turner's frontier thesis can only be understood in the light of this debate.

The frontier thesis was wedded to the gentry's response to the depression of $1893-$ 1897; a "searing experience" (Hofstadter, 1955, page 166). Turner weaves a course 
between the claims of the wage labourers/poor farmers and those of the big corporations, in exactly the same way that the Progressive politicians did. The rural and urban gentry united to guarantee the poiitical requirements of competitive capitalism in the fact of corporate and socialist challenges. The Progressive party embodied the "consumer revolt of the urban professional, clergy and intellectuals" (Hofstadter, 1955, page 137). In reacting to the threat to their social status posed by 'nouveau riche' millionaires at the head of large corporations, they stressed the values of the USA's past and presented a romantic critique of 'money power'. In fact, they offered just the sort of critique embodied in the 'agrarian myth', which they wrenched from any "farmer-labour coalition of the plain people" (Goodwyn, 1978, page 101) and pressed into the service of an alliance of richer farmers and urban gentry. Turner's history provided a historical rationale for these efforts by tying a specifically middle-class reading of the agrarian myth to the demands of the Progressive politicians. Ultimately, money power was able to reassert itself and the wealthy farmers chose to pursue their interests as the country wife of big business rather than as the rural cousin of the urban gentry. Turner's frontier thesis provided academic support for that tenuous rural-urban alliance which had reigned during the heyday of Progressive politics.

\section{Mackinder and closed space: geopolitics, tariff reform, and the age of exploration} Mackinder's use of these three components of closed-space theories is very different. The main thrust of his work is the imperative necessity of preparing for war, and his theoretical categories are based on a view of imperial policy as a geometry of power; as Parker remarks, "most of his multifarious statements find a place in a unifying imperial philosophy" (Parker, 1982, page 60). Geography, for Mackinder, is the "science whose main function is to trace the interaction of man in society and so much of his environment as varies locally" (Mackinder, 1887, page 143). This interaction varies in character with the time scale chosen. If we take a long-term view, the natural environment can be seen to have broken the human species up into several isolated units, which, through interaction with the environment, acquired those characteristics which set them apart as separate races: "John Bull is a local variety of the genus and species Homo sapiens. ... [I]n literal truth there is today in England a single blood, although with some provincial thickenings"' (Mackinder, 1931, page 326), and Mackinder expressed his agreement with Milner, who, he suggested, "believed in the English race. In other words, he believed in a certain blood, the carrier of a certain character, which it has taken tens of generations to evolve"' (Mackinder, 1925, page 726).

Then, in the shorter term, the natural environment provided the stage for the struggle of the races. In fact, "whether it squares with our ideals or not, we must regard the exercise of power in foreign affairs, in the present condition of the world, as a normal and peaceful function of the national life" (Mackinder, 1919, page 85). The evaluation of the strategic importance of various sectors of the world theatre of power was one of Mackinder's aims (compare Parker, 1982, pages 147-175 and 213247). He drew a distinction between the continental and the islander. Africa, Asia, and continental Europe formed the "World Island" (Mackinder, 1919, page 85).

There is an area of the 'World Island', termed by Mackinder the 'Heartland', which cannot be reached by sea and is thus safe from most attacks that might be made by the 'islanders'. It was from this region that the barbarians launched their attacks on Mediterranean civilisation, and, although these nomadic races lacked the man-power to do more than make sporadic forays, Mackinder believed that there was now "available a base of man-power sufficient to begin to threaten the liberty of the world from within this citadel of the World Island" (1919, page 143). From the beginning of the nineteenth century, Britain and France had endeavoured to prevent 
either Russia or Germany gaining complete control of this vast storchouse of natural resources. To secure the peace after the First World War, Mackinder suggested that this strategy be continued by kecping Germany and France apart with a string of independent and viable buffer states (Parker, 1982, pages 167-172).

Mackinder's history served a similar dual purpose. On one hand, it offers a theory of the development of communities, and, on the other, it presents an analysis of the nature of community conflict. The two are related, however, and the outcome of the latter is largely a consequence of a community's previous success in the former. 'The community exists in the 'liquid envelope' of the world, and a community's suceess in harnessing these circuits of water determines its mass. Consequently, for Mackinder, the "vast stable peasantries" of the East were primarily "a tremendous fact of rain, sap and blood" (Mackinder, 1931, page 329). Progress involves the fixing of ever more mass by a particular community. Effectively, suceess is reduced to power. For Mackinder, "The problem of problems for British statesmen at the present time concerns the adequacy of the basis of men and wealth upon which in the near future we may maintain peace by preparing adequately for war" (Mackinder, 1906, page 12). If "the communities of men should be looked on as units in the struggle for existence" (Mackinder, 1887, page 143), then progress is equated with survival, which is dependent on strength, which is linked to manpower, that is, to population and its quality. Mackinder, at different times, gave especial stress either to questions of the quantity or the quality of the population. Although, initially, he was more exercised by questions concerning the quality of the British race, after 1903 he laid much greater stress on its quantity (compare Semmel, 1960, pages 166-176). Mackinder believed that the British population would only increase if Britain could secure sufficient trade (see figure 1). Otherwise Britain would enter "that rank of states which exist on sufferance" (Mackinder, 1905, page 5). In the face of the increasing protection in the world market, the only possible solution was to incorporate the Empire into the home market by offering it a policy of 'imperial preference' and to place a tariff on the produce of the other powers. This, Mackinder suggested, would not reduce the total volume of British trade, since "to the foreign exporter" the British market was "the most valuable in the world" (Mackinder, 1906, page 21).

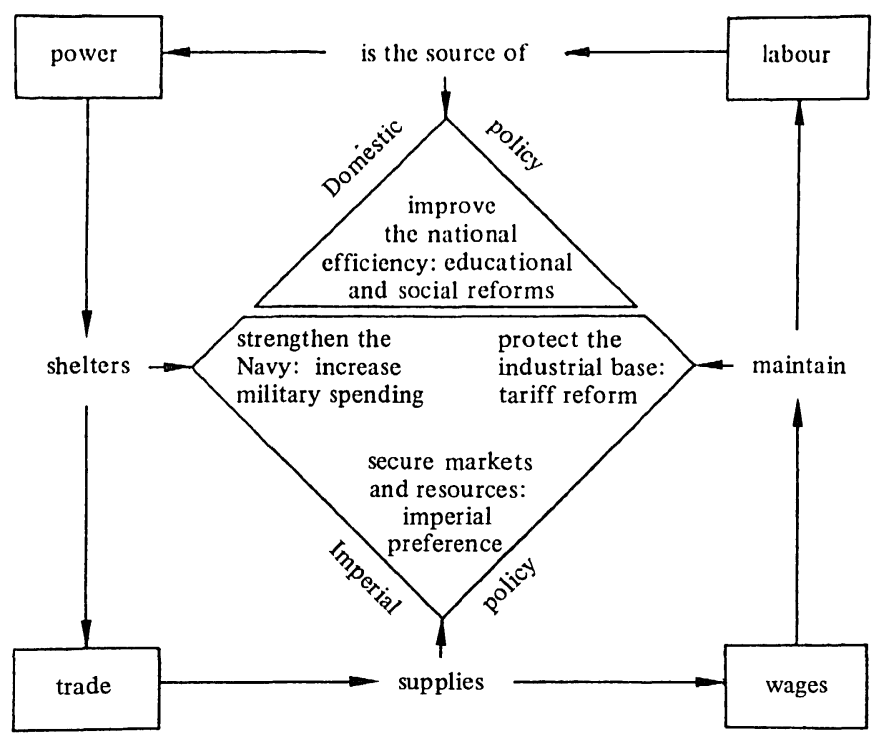

Figure 1. Mackinder's conception of the relations between power, trade, labour, and wages [based on Mackinder (1906, page 14) and Parker (1982, page 60)]. 
Mackinder believed that human history was the history of community conflict. The outcome of such struggles was determined by power and strategy. At various times, he held that policies of national efficiency, and later tariff reform, would increase British power, and he addressed his geopolitical writings to the second set of concerns.

Mackinder's use of the third component brings these two needs together by claiming a universal significance for his political analysis. The emergence of imperial strategy, as the solution to the problem of competition between powerful states, was taken by Mackinder to be the most important historical event for 400 years. $\mathrm{He}$ argued that, "for economic purposes, apart from the filling in of detail and from the small unknown regions remaining, the exploration of the world is finished" (Mackinder, 1900, page 267). The British were "presented with a closed system", for "there is no longer any elasticity of political expansion in lands beyond the Pale" (Mackinder, 1919, page 40). The four centuries (1500-1900) Mackinder labelled the age of Columbus were presented as unique in being a period of continual expansion against very weak opposition (see table 2). The exercise of world power by Britain was vital if the world organism was to continue to grow democratically. If the British race failed, then another race would become the world power. Initially, Mackinder expected the greatest threat to come from Germany, but increasingly after 1918 he came to fear that the eastern hordes would once more sweep over Europe and that the world would be subject to the rule of the "Bolshevik extremists" led by Lenin, "a poison which fermented" (Mackinder, 1924, pages 138 and 154).

Thus Mackinder used these three components to promote a politics of imperial power. Yet, just as Turner's work related to an unstable coalition of political interests, Mackinder's efforts to provide a case for imperial policies came up against serious economic contradictions. Semmel (1960, pages 141-165) has described two varieties of early-twentieth-century British imperialism: cosmopolitan and mercantilist. Mackinder's work contains elements of both positions, but the scales were gradually tipped in favour of the latter (compare Mackinder, 1900, and Mackinder, 1906). Politically, this entailed a shift from a group known as the Liberal Imperialists who believed in free trade and supported the interests of the city, to, after 1903, a group known as the Liberal Unionists, who supported the use of tariffs to protect markets and to safeguard the interests of industrialists (see Matthew, 1973, page 259 and Mackenzie and Mackenzie, 1979, page 300). These economic contradictions and the political fragmentation they caused were temporarily resolved by the policies of the wartime economy. Only war could satisfy the interests of the bankers who would finance it and the industrialists who would produce the hardware. Mackinder's advocacy of mercantilist imperialism anticipated such a war, and he was evidently impressed by the efficiency of a planned wartime economy because, around the policies needed to organise carefully the economy as a 'going concern', he came to

Table 2. Mackinder's summary of the evolution of the world organism [based on Mackinder (1904, passim) and Parker (1982, page 242)].

\begin{tabular}{|c|c|c|c|}
\hline \multirow{2}{*}{$\begin{array}{l}\text { Characteristics of the } \\
\text { world organism }\end{array}$} & \multicolumn{3}{|l|}{ Period in history } \\
\hline & medieval Christendom & $\begin{array}{l}\text { age of Columbus } \\
(1500-1900)\end{array}$ & post-Columbian age \\
\hline Geopolitical conditions & external barbarism & $\begin{array}{l}\text { unopposed } \\
\text { expansion }\end{array}$ & $\begin{array}{l}\text { no lands left to } \\
\text { conquer }\end{array}$ \\
\hline Political system & closed & open & closed \\
\hline Scope & Europe & World & World \\
\hline Dominant form of power & land & sea & land \\
\hline Result & nations & empires & world empire \\
\hline
\end{tabular}


see the possibility of uniting the two imperialisms. Semmel (1960, page 175) writes that: "In 1919, Mackinder published a volume entitled Democratic leleals and Reality in which he extracted the essences of both Free Trade and tariff imperialism and proclaimed their inherent sameness. The imperialists of both persuasions were 'organisers', he explained; their enemies ... were 'idealists'".

\section{Closed space, context, and choice}

Turner and Mackinder, therefore, took up issues of contemporary concern and pursued them in distinctly spatial ways through closed-space theories. Closed-space theories represented an overlap between geography, biology, and public debate. Turner and Mackinder made a series of political choices and oriented their work towards particular political alliances. Other academics oriented closed-space theories in different ways. For example, in the USA, Sumner developed themes which were closer to Mackinder's concerns than they were to Turner's, although he believed, unlike Mackinder, that political imperialism was undesirable whereas economic imperialism would be highly valuable (Sumner, 1934). Similarly, in Britain, James Bryce (like Mackinder, a university professor, a Member of Parliament, and a Fellow of the Royal Geographical Socicty) used closed-space theories to protest against political imperialism and to promote the radical Libcral policy of national selfdetermination, speaking of "a contraction of the world, the overflow of the advanced races and the consequent diffusion all over the world of what is considered civilisation" (Weinroth, 1974, page 220). Yet, for all these differences, this period does represent an episode in the development of geography when spatial perspectives were particularly relevant to public debate. The terms on which this 'relevance' was achieved were specific to this period, but they were undermined by the late 1920s as the optimism of biology gradually gave way to the doubt of relativity physics and statistics. By explaining how external influences operate on and within geography, a properly contextual approach might contribute to the understanding of such shifts.

Acknowledgements. An earlier version of this paper was presented to the Cukansus conference in Los Angeles, 1979. I would like to thank everyone who made it possible for me to attend, especially Sidney Sussex College, Cambridge and the Historical Geography Research Group, London. I would also like to thank the members of the Occasional Discussions in Historical Geography at Cambridge, the First Floor Forum at the Department of Geography, Liverpool, and the following: A Baker, C Bates, R Block, S Corbridge, H C Darby, N Entrikin, R Fanthorpe, $\mathrm{T} W$ Freeman, J Gibson, W Gould, D Gregory, B Harley, R Lawton, J Peel, H Prince, D Shaw, and M Williams.

\section{References}

Benson L, 1969, "The historian as mythmaker: Turner and the world frontier" in The Frontier in American Development: Essays in Honour of Paul Wallace Yates Ed. D M Ellis (Cornell University Press, Ithaca, NY) pp 3-19

Billington R A, 1973 Frederick Jackson Turner: Historian, Scholar, Teacher (Oxford University Press, New York)

Blouet B W, 1975, "Sir Halford Mackinder, 1861-1947: some new perspectives" research paper 13, School of Geography, University of Oxford, Oxford, England

Burrow J W, 1966 Evolution and Society: A Study in Victorian Social Theory (Cambridge University Press, Cambridge)

Capel H, 1981, "Institutionalisation of geography and strategies of change" in Geography, Ideology and Social Concern Ed. D R Stoddart (Basil Blackwell, Oxford) pp 37-69

Collini S, 1979 Liberalism and Sociology: L T Hobhouse and Political Argument in England, 18801914 (Cambridge University Press, Cambridge)

Freeden M, 1978 The New Liberalism: An Ideology of Social Reform (Clarendon Press, London)

Freunde R, 1945, “Turner's theory of social evolution" Agricultural History 19 78-87

Gilbert E W, 1951, "Seven lamps of geography: an appreciation of the teaching of Sir Halford Mackinder" Geography $3621-43$

Goodwyn L, 1978 The Populist Movement: A Short History of the Agrarian Revolt in America (Oxford University Press, London) 
Hindess B, 1977 Philosophy and Methodology in the Social Sciences (Harvester Press, Hassocks, Sussex) Hofstadter R, 1944 Social Darwinism in American Thought (University of Pennsylvania Press,

Philadelphia, PA)

Hofstadter R, 1955 The Age of Reform (Alfred Knopf, New York)

Hofstadter R, 1970 The Progressive Historians: Turner, Beard, Parrington (Vintage Books, New York)

Johnston R J, 1979 Geography and Geographers: Anglo-American Human Geography Since 1945 (Edward Arnold, London)

MacCarthy T, 1978 The Critical Theory of Jurgan Habermas (Hutchinson, London)

Mackenzie N, Mackenzie J, 1979 The First Fabians (Quartet Books, London)

Mackinder H J, 1887, "On the scope and methods of geography" Proceedings of the Royal Geographical Society $9141-160$

Mackinder H J,1900, "The great trade routes" Journal of the Institute of Bankers 21 137-155, 266273

Mackinder H J, 1904, "The geographical pivot of history" Geographical Journal 23 421-437

Mackinder H J, 1905, "Manpower as a measure of national and imperial strength" National and English Review 45 136-143

Mackinder H J, 1906 Money-Power and Man-Power: The Underlying Principles Rather Than the Statistics of Tariff Reform (Simpkin Marshall, London)

Mackinder H J, 1908 The Development of Geographical Teaching out of Nature Study (George Philip and Son, London)

Mackinder H J, 1919 Democratic Ideals and Reality: A Study in the Politics of Reconstruction (Constable, London)

Mackinder H J, 1924 The World War and After: A Concise Narrative and Some Tentative Ideas (George Philip and Son, London)

Mackinder H J, 1925, “'The English tradition and the empire: some thoughts on Lord Milner's credo and the Imperial Committees" United Empire 16 724-735

Mackinder H J, 1931, "The human habitat" Scottish Geographical Magazine 47 321-335

Mackinder H J, 1934, "The Empire and the World" United Empire 25 519-522

Malin J C, 1944, "Space and history: reflections on the closed-space doctrines of Turner and Mackinder and the challenge of those ideas by the air age" Agricultural History 18 65-74

Matthew H C G, 1973 The Liberal Imperialists: The Ideas and Politics of a Post-Gladstonian Elite (Oxford University Press, London)

Mood F (Ed.), 1949, "Frederick Jackson Turner's address on education in a United States without frontier lands" Agricultural History 23 254-259

Morris J, 1979 Pax Brittanica: The Climax of an Empire (Penguin Books, Harmondsworth, Middx)

Noble D W, 1965 Historians Against History: The Frontier Thesis and the National Covenant in American Historical Writing Since 1830 (University of Minnesota Press, Minneapolis, MN)

Parker W H, 1982 Mackinder: Geography as an Aid to Statecraft (Clarendon Press, London)

Russett C E, 1976 Darwinism in America: The Intellectual Response (W H Freeman, New York)

Semmel B, 1960 Imperialism and Social Reform: English Social-Imperialist Thought 1895-1914 (George Allen and Unwin, Hemel Hempstead, Herts)

Stoddart D R, 1975, "That Victorian science: Huxley's 'physiography' and its impact on geography" Transactions of the Institute of British Geographers 66 17-40

Stoddart D R, 1981 a, "Geography, education and research" Geographical Journal 147 287-297

Stoddart D R (Ed.), 1981b Geography, Ideology and Social Concern (Basil Blackwell, Oxford)

Sumner W G, 1934, "Earth hunger or the philosophy of land-grabbing" in Essays of William Graham Sumner volume 1, Ed. A G Keller (Yale University Press, New Haven, CT) pp 174-207

Teymur N, 1982 Environmental Discourse: A Critical Analysis of 'Environmentalism' in Architecture, Planning, Design, Ecology, Social Sciences and the Media (Question Press, London)

Turner F J, 1920a, "Contributions of the West to American democracy" in The Frontier in American History Ed. F J Turner (Holt, Rinehart and Winston, New York), pp 243-268

Turner F J, 1920b, "Pioneer ideals and the state university" in The Frontier in American History Ed. F J Turner (Holt, Rinehart and Winston, New York) pp 269-289

Turner F J, 1920c, "The significance of the frontier in American history" in The Frontier in American History Ed. F J Turner (Holt, Rinehart and Winston, New York) pp 1-38

Weinroth H, 1974, "Radicalism and nationalism: an increasingly unstable equation" in Edwardian Radicalism 1900-1914: Some Aspects of British Radicalism Ed. A J A Morris (Routledge and Kegan Paul, Henley-on-Thames, Oxon) pp 218-233 